\title{
Identifying Unique Characteristics of Disassembly for Various Product Recovery Methods with A Focus on Remanufacturing
}

\author{
Anjar Priyono ${ }^{1}$ \\ ${ }^{1}$ Department of Management, Universitas Islam Indonesia
}

\begin{abstract}
This paper aims to identify differences between disassembly for three product recovery methods: remanufacturing, recycling, and repair. Existing studies focus on disassembly differences for the three recovery methods from technical perspective only; those studies focus on the level of disassembly and the method of disassembly. This study covers various aspects of disassembly such as knowledge of worker, value of the materials, and interplays with other processes in product recovery. As many as seven products were use d as case studies were undertaken to identify differences of disassembly for three recovery methods. At the end of the paper, managerial implications are presented.
\end{abstract}

\section{Introduction}

Remanufacturing falls under the major theme of sustainable manufacturing, which has received considerable attention in recent years. There is a growing trend within government bodies, such as European Union Directives, Waste Electrical and Electronic Equipment (WEEE), Kyoto Protocol and End-of-Life Vehicles (ELV) in favour of adopting more environmentally friendly manufacturing practices and regulations. Economic analysis has shown remanufacturing to be a prospective business [1] and it is environmentally friendly from an ecological perspective [2]. This is because remanufacturing is not only viewed as an effective way to minimise discarded waste, but also as part of a company's manufacturing and marketing strategy [3].

In terms of product types, automotive products are the most common [3], but other product types, such as photocopiers [8, 11, 12], forklift trucks [7], toner cart ridge [7] and telecommun ication devices [7, 14] are all gaining in popularity. This evidence indicates that remanufacturing has spread widely across many countries and product types.

This significant increase in attention towards remanufacturing practices suggests that more studies in this area are badly needed. Such a study would contribute to a better understanding of remanufacturing, which would in turn lead to more economically feasible and environmentally friendly manufacturing practices. This research aims to fill this particular need by investigating how disassembly for remanufacturing process is different from that of other recovery methods.

Through the better understanding of the disassembly process, remanufacturing performance can be improved by minimising uncertainties [10], with disassembly being one of the main causes. Equally important are the uncertainties that result from disassembly and how these affect other processes in remanufacturing. As a result, better-managed disassembly will lead to more economically efficient remanufacturing operations.

Disassembly is a critical element of product recovery activities, as it is the key link that connects product return with product recovery, and a prerequisite for some processes [11]. Disassembly is a prerequisite for reprocessing and re-machining because the processes cannot be carried out whilst the components are still embedded in the products. In other processes, for example cleaning and testing, the components do not have to be entirely disassembled from the products; however, partial disassembly may still be necessary.

In this case, products must be disassembled to a certain level in order to give access to certain components so that cleaning and testing can be carried out. Without disassembly it may not be possible for other processes in remanufacturing to be undertaken, which would mean the products could not be remanufactured.

Disassembly is also the main gateway of information, where many data that is related to the remanufacturing operations originates $[17,18]$. Information is valuable in order to minimise any uncertainties in activities that are related to remanufacture, such as purchasing new parts, inventory management and production planning, and scheduling [19-21]. The importance of information from disassembly increases when remanufacturers deal with complex products [14].

Uncertainties that arise on the disassembly shop floor can affect other processes in remanufacturing. During disassembly, not all of the parts can be recovered. It is rare to achieve full recovery rates, so there is an increase in the need for new parts [13]. As disassembly is cited as 
the main source of parts during reassembly [16] and availability of parts is the most costly operation in remanufacturing [17].

Based on the significance of successful disassembly demonstrated above, the overall remanufacturing process can be enhanced by improving disassembly. Hammond et al. [17] state in their survey report that disassembly is one of the most serious problems found in remanufacturing and, therefore, improving disassembly could improve overall remanufacturing processes. The ability to manage disassembly is the key to success for remanufacturers because it affects several other parameters, including lead times, price, delivery and quality [18].

There has been an abundance of research conducted regarding disassembly that concentrates on product disassembly as the focus of the investigation [19]. Many of the studies that investigate disass embly do not mention the ultimate purpose of product recovery from disassembly. The final purpose of disassembly is important because disassembly for remanufacturing is different from that of other recovery methods. The output of remanufacturing should be able to offer quality performance at the same level, or higher, than the new condition, whereas other recovery methods do not offer such a performance specification $[22,27]$. Therefore, the relevant research question is as follow: How does disassembly for remanufacturing differs from that of other recovery methods?

The remainder of this paper is organised into 3 sections. Next section describes the method used to conduct this study. Section 3 discuss es the findings and analysis. Existing studies in this topic are also discussed in the section. Section 4, last section, summarises the key findings of this paper.

\section{Method}

This study adopt inductive approach to analyse disassembly for different recovery methods. Also, multiple case study method was selected to allow researcher undertake within and cross case analysis [22] as well as direct and indirect replication logic [23]. Interview, observation, and ompany visits were conducted to collect data. In the company visits there were observations, interviews, document checks and discussion. Four companies that reproses various products participated in this study. In total there are 7 product types investigated in this study, including gearbox, clutches, jet engine, car engine, photocopier, truck engine, and heavy equipment.

\section{Findings and Analysis}

\subsection{Existing concepts in disassembly}

Several studies examine the differences between disassembly for remanufacturing and that for other recovery methods; these are presented in Table 1.
Table 1. Output and disassembly level differences across various end-of-life strategies

\begin{tabular}{|c|c|c|}
\hline $\begin{array}{c}\text { End-of-life } \\
\text { strategies }\end{array}$ & Disassembly level & References \\
\hline Remanufacturing & Total disassembly & {$[21]$} \\
\hline Recycling & Total disassembly & {$[21]$} \\
\hline Repairing & Partial disassembly & {$[22,27,28]$} \\
\hline Reconditioning & Partial disassembly & {$[22,27]$} \\
\hline
\end{tabular}

Source: adapted from [3]

From the perspective of the new process model of disassembly that use a comprehensive perspective [11], the above table has several drawbacks. First, the differences highlighted focus on level of disassembly only, which is related to 'hard' factors. By contrast, 'soft' factors, such as data and information about products, skills of employes, as well as an economic consideration of disassembly, are not discussed [25].

The differences above also ignore the suggestion by existing literature that disassembly can be improved using early information. For example, the development of embedded devices can provide data that can be used to support disassembly [29, 30]. Such technology can assist in reducing the amount of work involved in the process and, consequently, remanufacturers can carry out disassembly more efficiently [26]. In addition, from a strategic perspective, developing organisational relationship with OEMs would be helpful in obtaining product specifications [3], [28]. These specifications are useful as they assist remanufacturers in preparing a facility to carry out disas sembly.

Second, the studies detailed above assume that disassembly is an independent activity, ignoring the fact that disassembly in remanufacturing is related to other processes. Coordination with other processes, such as material requirement planning (MRP), bill of material (BOM) and purchase of new parts should also be considered [29].

Further adding to the complexity of discussion is differences between the work content, warranty and quality of output in a remanufacturing context compared to disassembly for repair, reconditioning or recycling [24] The differences between the three recovery methods, in terms of these parameters, are presented graphically in Figure 1. If highlighted, these differences can aid a better understanding of how disassembly for the three recovery methods is not identical.

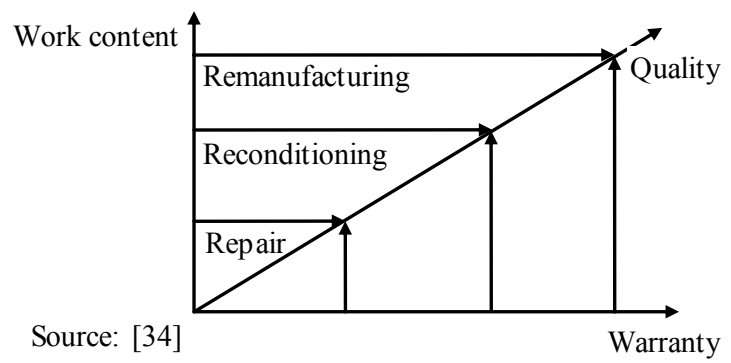

Figure 1. Hierarchy of secondary production processes 


\subsection{Comparing disassembly for remanufacturing and recycling}

When distinguishing the differences between disassembly for remanufacturing and disassembly for recycling, it is important to stress the sources of the recovered value of the cores. The recovered value of cores comes from two sources: (1) the materials used to make the components, and (2) the manufacturing process which made the components. These two sources of recovered value differ in importance between remanufacturing and recycling. In remanufacturing, both sources of recovered value are important, whilst in recycling, only the value that derives from materials is considered.

Table 2. Differences between disassembly for remanufacturing and recycling.

\begin{tabular}{|c|l|l|l|}
\hline No. & \multicolumn{1}{|c|}{ Issue } & \multicolumn{1}{|c|}{$\begin{array}{c}\text { Remanu- } \\
\text { facturing }\end{array}$} & \multicolumn{1}{|c|}{ Recycling } \\
\hline 1. & $\begin{array}{l}\text { Method to } \\
\text { disassemble. }\end{array}$ & $\begin{array}{l}\text { Destructive } \\
\text { disassembly is } \\
\text { not allowed. }\end{array}$ & $\begin{array}{l}\text { Both destructive } \\
\text { and non- } \\
\text { destructive } \\
\text { methods are } \\
\text { possible. }\end{array}$ \\
\hline 2. & $\begin{array}{l}\text { Priority to } \\
\text { recover. }\end{array}$ & $\begin{array}{l}\text { Consider both } \\
\text { the value that } \\
\text { comes from the } \\
\text { manufacturing } \\
\text { process and the } \\
\text { materials to } \\
\text { make the } \\
\text { products. }\end{array}$ & $\begin{array}{l}\text { Only considers the } \\
\text { value of materials } \\
\text { to make the } \\
\text { products. }\end{array}$ \\
\hline 3. & $\begin{array}{l}\text { Coordination } \\
\text { of } \\
\text { disassembly } \\
\text { with BOM } \\
\text { and MRP }\end{array}$ & $\begin{array}{l}\text { There needs to } \\
\text { be coordination } \\
\text { with BOM and } \\
\text { MRP. }\end{array}$ & $\begin{array}{l}\text { There is no need } \\
\text { for any kind of } \\
\text { coordination, as } \\
\text { the disassembled } \\
\text { components are } \\
\text { going to be melted } \\
\text { into materials, not } \\
\text { to be reassembled. }\end{array}$ \\
\hline
\end{tabular}

In recycling, companies attempt to recover the value from materials, regard less of how high the potential value from the manufacturing process is. As the condition of the components is irrelevant, the destructive method is allowed in recycling. Components made from materials with higher value will be given prio rity. Two components that are made from the same materials would be treated in the same way during disassembly, even if the residual value of one component was higher than the other, for example if one of the components had a higher value due to a more complex manufacturing process, complex product structure or rare component.

In remanufacturing, however, both sources of recovered value are considered. For this reason, components made from less expensive materials might be given priority, rather than components that are made from more expensive materials. This is because the former has undergone complex production processes that make the residual value higher compared to the latter one. It is the shape of the components that makes the residual value high, not the materials used to make them. Furthermore, disassembly in recycling does not produce information about the recovery rates of components and it does not require the forecasting of new parts. The summary of all the differences is presented in Table 2.

\subsection{Comparing disa ssembly for remanufacturing and repairing}

As there is a need to ensure that the output of remanufacturing is equal to, or higher than, the new ones $[22,33,34]$, compulsory disassembly has to be undertaken. This occurs because there are parts that must be replaced with new ones, regardless of the condition, in order to comply with legislation requirements, OEM standards or company policies. Parts are replaced because they have been identified as being typically worn out, a potential risk to the user, or have a limited amount of life remaining. In some circumstances, the parts are not necessarily replaced with new ones, but all the parts should be tested in order to ensure that they meet acceptable quality standards. In this case, the parts still have to be disas sembled.

On the other hand, repairing that aims to bring back the functionality of products $[22,27]$ does not require any compulsory disassembly. Components are disassembled only if they are related to the fault of the products. There is no leg islation, company policy or OEM standards that requires specific components to be replaced with new ones. Used components can be reinstalled in the products, provided that they function normally.

From an economic perspective, compulsory disassembly, which is found in remanufacturing, is not efficient, since remanufacturers have to carry out disassembles which are not always necessary [35, 36]. Even components whose conditions are almost equal to new ones have to undergo disassembly. As a result, there might be unnecessary activities conducted by remanufacturers. In contrast, when it comes to repairing, components are only disassembled when it is necessary, for example to enable emp loyees to carry out work on the components and restore the functionality of the products. The summary of these differences is provided in Table 3 .

Table 3. Differences between disassembly for remanufacturing and repairing.

\begin{tabular}{|c|l|l|l|}
\hline No. & \multicolumn{1}{|c|}{ Issue } & \multicolumn{1}{c|}{$\begin{array}{c}\text { Remanu- } \\
\text { facturing }\end{array}$} & \multicolumn{1}{c|}{ Repairing } \\
\hline 1. & $\begin{array}{l}\text { Compulsory } \\
\text { to } \\
\text { disassemble. }\end{array}$ & $\begin{array}{l}\text { There are } \\
\text { compulsory } \\
\text { disassembly. }\end{array}$ & $\begin{array}{l}\text { There is no } \\
\text { compulsory } \\
\text { disassembly. }\end{array}$ \\
\hline 2. & $\begin{array}{l}\text { Economics } \\
\text { of } \\
\text { disassembly. }\end{array}$ & $\begin{array}{l}\text { Not always } \\
\text { economically } \\
\text { efficient. }\end{array}$ & $\begin{array}{l}\text { More efficient } \\
\text { economically } \\
\text { than disassembly } \\
\text { for } \\
\text { remanufacturing. }\end{array}$ \\
\hline
\end{tabular}

\subsection{Comparing disassembly for remanufacturing and reconditioning}

Remanufacturing needs higher level of disassembly than reconditioning. This is because the resulting output of reconditioning is lower than the new products, while the output of remanufacturing is equal to or higher than the new products [22, 27, 37]. For this reason, 
remanufacturing requires more work and higher standards than reconditioning does [34] - see Figure 1. To permit more work in remanufacturing, there would have to be a higher level of disassembly than there is in reconditioning. More work in this regard refers to any remanufacturing processes, such as a more detailed inspection, more detailed testing, or a tighter criteria for sorting and inspection. On the other hand, the output of reconditioning has lower standards, which is not necessarily as strict as the criteria for new products. Disassembly for reconditioned products does not need to ensure that the quality of the resulting products is the same as new ones. There is no need to carry out disassembly, provided that the modules or parts reach acceptable quality standards.

Table 4. Differences between disassembly for remanufacturing and reconditioning.

\begin{tabular}{|c|l|l|l|}
\hline No. & \multicolumn{1}{|c|}{ Issue } & \multicolumn{1}{c|}{$\begin{array}{c}\text { Remanu- } \\
\text { facturing }\end{array}$} & $\begin{array}{c}\text { Recondi- } \\
\text { tioning }\end{array}$ \\
\hline 1. & $\begin{array}{l}\text { Level of } \\
\text { disassembly }\end{array}$ & $\begin{array}{l}\text { Have higher level } \\
\text { than } \\
\text { reconditioning }\end{array}$ & $\begin{array}{l}\text { Have lower } \\
\text { level than } \\
\text { remanu- } \\
\text { facturing. }\end{array}$ \\
\hline 2. & $\begin{array}{l}\text { Compulsory } \\
\text { disassembly }\end{array}$ & $\begin{array}{l}\text { There are } \\
\text { compulsory } \\
\text { disassembly } \\
\text { activities that } \\
\text { should be carried } \\
\text { out. }\end{array}$ & $\begin{array}{l}\text { There is no } \\
\text { compulsory } \\
\text { disassembly } \\
\text { activities that } \\
\text { should be } \\
\text { carried out. }\end{array}$ \\
\hline
\end{tabular}

As discussed previously, there are mandatory component replacements in remanufacturing. This causes compulsory disassembly, which is not always economically efficient. On the other hand, reconditioning does not need mandatory component replacements. As long as the components are still in acceptable condition, they are not disassembled. Thus, disassembly in reconditioning is only carried out whenever necessary to do. From economic perspective, this disassembly is more economically efficient than disassembly for mandatory component replacement. The summary of the difference is presented in Table 4.

\section{Conclusion}

This study offers insights regarding the differences of disassembly for three recovery methods : remanufacture, repair, and recycle. In this study, disassembly for the three recovery methods was analysed comprehensively. It is not only about the level, the method, and sequence of disassembly, but also about skills of emp loyees as well as knowledge regarding the specification of new products. The knowledge is required to ensure that the results of remanufacturing process is equal or higher than the new one.

\section{References}

1. R. Subramoniam, D. Huisingh, and R. B. Chinnam, "Remanufacturing for the automotive aftermarketstrategic factors: literature review and future research needs," J. Clean. Prod., vol. 17, no. 13, pp. $1163-$ 1174, Sep. 2009.

2. G. D. Hatcher, W. L. Ijomah, and J. F. C. W indmill, "Design for remanufacture: a literature review and future research needs," J. Clean. Prod., vol. 19, no. 17-18, pp. 2004-2014, Nov. 2011.

3. Y. M. B. Saavedra, A. P. B. Barquet, H. Rozenfeld, F. a. Forcellini, and A. R. Ometto, "Remanufacturing in Brazil: case studies on the automotive sector," $J$. Clean. Prod., vol. 53, pp. 267-276, Aug. 2013.

4. B. Walsh, "An assessment of the remanufacture of photocopier equipment commissioned by Market Transformation Programme," Cent. Remanufacturing Reuse, no. May, pp. 1-14, 2009.

5. K. Mukherjee and S. Mondal, "Analysis of issues relating to remanufacturing technology - a case of an Indian company," Technol. Anal. Strateg. Manag., vol. 21, no. 5, pp. 639-652, Jul. 2009.

6. A. King, J. Miemczyk, and D. Bufton, "Photocopier remanufacturing at Xerox UK," in D. Brissaudet al. (eds.) Innovation in life cycle engineering and sustainable development., 2006, pp. 173-186.

7. J. Östlin, E. Sundin, and M. Björkman, “Importance of closed-loop supply chain relationships for product remanufacturing," Int. J. Prod. Econ., vol. 115, no. 2, pp. 336-348, Oct. 2008.

8. C. Franke, B. Basdere, M. Ciupek, and S. Seliger, "Remanufacturing of mobile phones-capacity, program and facility adaptation planning," Omega, vol. 34, no. 6, pp. 562-570, Dec. 2006.

9. P. Rathore, S. Kota, and A. Chakrabarti, "Sustainability through remanufacturing in India: a case study on mobile handsets," J. Clean. Prod., vol. 19, no. 15 , pp. $1709-1722$, Oct. 2011.

10. K. H. A ksoy and S. M. Gupta, "Near optimal buffer allocation in remanufacturing systems with $\mathrm{N}$ policy," Comput. Ind. Eng., vol. 59, no. 4, pp. 496508, Nov. 2010.

11. A. Priyono, W. Ijomah, and U. Bit itci, "Disassembly for remanufacturing - A systematic literature review, new model development and future research needs," J. Ind. Eng. Manag. JIEM, vol. 9, no. 4, pp. 2016-9, 2016.

12. M. L. Junior and M. G. Filho, "Production planning and control for remanufacturing: literature review and analysis," Prod. Plan. Control, vol. 23, no. 6, pp. 37-41, 2012.

13. V. Guide Jr., "Production planning and control for remanufacturing: Industry practice and research needs,"J. Oper. Manag., vol. 18, pp. 467-483, 2000.

14. G. Ferrer and M. E. Ketzenberg, "Value of information in remanufacturing complex products," IIE Trans., vol.36, no. 3, pp. 265-277, Mar. 2004.

15. G. Ferrer, "Yield information and supplier responsiveness in remanufacturing operations," Eur. J. Oper. Res., vol. 149, no. 3, pp. 540-556, Sep. 2003.

16. G. Ferrer and D. C. Whybark, "Material planning for a remanufacturing facility," Prod. Oper. Manag., vol. 10, no. 2, pp. 112-124, Jan. 2001.

17. R. Hammond, T. A mezquita, and B. Bras, "Issues in the automotive parts remanufacturing industry - A discussion of results from surveys performed among 
remanufacturers," Int. J. Eng. Des. Autom. - Spec. Issue Environ. Conscious Des. Manuf., vol. 4, no. 1, pp. 27-46, 1998.

18. J. R. Duflou, B. Willems, and W. Dewulf, "Towards self-disassembling products design solutions for economically feasible large-scale disassembly," in $D$. Brissaud et al. (eds.), Innovation in Life Cycle Engineering and Sustainable Development, 2006, pp. 87-110.

19. M. A. Ilgin and S. M. Gupta, "Environmentally conscious manufacturing and product recovery (ECMPRO): A review of the state of the art.," $J$. Environ. Manage., vol. 91, no. 3, pp. 563-91, 2010.

20. W. Ijomah, S. Childe, and C. McMahon, "Remanufacturing - a key strategy for sustainable development.," in Proceedings of the third international conference on design and manufacture for sustainable development, September 1-2, 2004 Loughborough, UK., 2004.

21. M. Thierry, M. Salomon, J. Van Nunen, and L. Van Wassenhove, "Strategic issues in product recovery management," Calif. Manage. Rev., vol. 37, no. 2, pp. 114-135, 1995.

22. K. M. Eis enhardt, "Build ing theories from case study research," Acad. Manag. Rev., vol. 14, no. 4, pp. 532-550, 1989.

23. R. K. Yin, Case study research: Design and methods, 4th ed. London, United Kingdom.: Sage Publications, Inc., 2009.

24. W. L. Ijomah, C. A. McMahon, G. P. Hammond, and S. T. Newman, "Development of robust design-forremanufacturing guidelines to further the aims of sustainable development," Int. J. Prod. Res., vol. 45, no. 18-19, pp. 4513-4536, Sep. 2007.

25. A. Priyono, W. L. Ijomah, and U. S. Bititci, "Strategic operations framework for disassembly in remanufacturing," J. Remanufacturing, vol. 5, no. 11, pp. 1-16, 2015.
26. M. A. Ilg in and S. M. Gupta, "Comparison of economic benefits of sensor embedded products and conventional products in a multi-product disassembly line," Comput. Ind. Eng., vol. 59, no. 4, pp. 748-763, Nov. 2010.

27. O. Ondemir and S. M. Gupta, "Quality management in product recovery using the Internet of Things: An optimization approach," Comput. Ind., vol. 65, no. 3, pp. 491-504, Apr. 2014.

28. S. Lind, D. Olsson, and E. Sundin, "Exploring interorganizational relationships in automotive component remanufacturing," J. Remanufacturing, vol. 4, no. 1, pp. 1-14, 2014.

29. H. B. Lee, N. W. Cho, and Y. S. Hong, "A hierarchical end-of-life decision model for determining the economic levels of remanufacturing and disassembly under environmental regulations," $J$. Clean. Prod., vol. 18, no. 13, pp. 1276-1283, Sep. 2010.

30. R. T. Lund, Remanufacturing: the experience of the USA and implications for the developing countries. Washington, D.C.: World Bank, 1984.

31. W. L. Ijomah, "A tool to improve training and operational effectiveness in remanufacturing," Int. J. Comput. Integr. Manuf., vol. 21, no. 6, pp. 676-701, Sep. 2008.

32. A. Desai and A. Mital, "Evaluation of disassemblability to enable design for disassembly in mass production," Int. J. Ind. Ergon., vol. 32, no. 4, pp. 265-281, Oct. 2003.

33. M. R. Johnson and M. H. Wang, "Planning product disassembly for material recovery opportunities," Int. J. Prod. Res., vol. 33, no. 11, pp. 3119-3142., 1995.

34. W. L. Ijomah, C. A. McMahon, G. P. Hammond, and S. T. Newman, "Development of design for remanufacturing guidelines to support sustainable manufacturing," Robot. Comput. Integr. Manuf., vol. 23, no. 6, pp. 712-719, Dec. 2007. 